De Takats, G., and Quint, H. (1930). Surgery, Gynecology, and Obstetrics, 50, 545 .

Dodd, H. (1964). Lancet, 2, 809.

Dodd, H., and Cockett, F. B. (1956). The Pathology and Surgery of the Veins of the Lower Limb, p. 3. Edinburgh, Livingstone.

Foote, R. R. (1960). Varicose Veins : A Practical Manual, 3rd ed., p. 1. Bristol, Wright.

Hawkes, S. Z., and Hewson, G. F. (1940). Surgery, 7, 714.

Howard, J. B. (1966). The Epidemiology of Varicose Veins in an Industrial Population, M.D. Thesis, Yale University, U.S.A.

Keen, W. W. (1908). Surgery: Its Principles and Practice, edited by W. W. Keen and J. C. Da Costa, vol. 4, p. 1149. Philadelphia, Lippincott.

Khosla, T., and Lowe, C. R. (1967). British fournal of Preventive and Social Medicine, 21, 122.
Lake, M., Pratt, G. H., and Wright, I. S. (1942). Fournal of the American Medical Association, 119, 696.

Lewis, J. H. (1942). The Biology of the Negro. Chicago, University

Lockhart-Mummery, H. E., and Smitham, J. H. (1951). British fourmal of Surgery, 38, 284.

Ludbrook, J., and Beale, G. (1962). Lancet, 1, 79.

Ochsner, A., and Mahorner, H. (1937). Surgery, 2, 889.

Phillips, R. S. (1963). Archives of Surgery, 87, 732

Ribaudo, C. A., and Formato, A. A. (1965). New York State fournal of Medicine, 65, 456.

Sevitt, S., and Gallagher, N. (1961). British fournal of Surgery, 48, 475.

Stamler, J. (1958). Fournal of the National Medical Association, 50, 161

Thomas, W. A., Davies, J. N. P., O'Neal, R. M., and Dimakulangan, A. A. (1960). American fournal of Cardiology, 5, 41 .

\title{
Plasma 11-Hydroxycorticosteroid and Growth Hormone Levels in Acute Medical Illnesses
}

\author{
H. S. JACOBS,* M.B., B.CHIR., M.R.C.P. ; J. D. N. NABARRO, † M.D., F.R.C.P.
}

Summary : Adrenal cortical response in acute medical illness has been studied by measuring the plasma 11-hydroxycorticosteroid (11-OHCS) concentration in 178 patients. Those with unbalanced diabetes, acute infections, and severe myocardial infarction had high levels. The results obtained suggest that in a patient with a severe infection and hypotension a plasma 11-OHCS level of less than $15 \mu \mathrm{g} . / 100 \mathrm{ml}$. indicates an inadequate adrenal cortical response, and one patient with septicaemia and temporary adrenal cortical insufficiency is described. Growth hormone levels were increased in patients with severe diabetic ketosis but not in those with hyperosmolar non-ketotic diabetic coma.

\section{Introduction}

Patients with primary or secondary impairment of adrenal cortical function may respond poorly to any acute illness, injury, or surgical operation, and unless adequate steroid cover is given circulatory failure with severe hypotension may occur. Cortisone and its synthetic analogues have been given to patients with acute illnesses and severe hypotension on the assumption that there may be an inadequate adrenal cortical response to the illness. An attempt has therefore been made to determine the magnitude of adrenal cortical response in a wide range of acute medical conditions by measuring plasma 11-OHCS levels. In many of the patients plasma growth hormone concentrations were also measured.

\section{Methods}

Most of the patients were studied on admission to medical wards because of acute conditions, and a few were seen in other wards of the hospital when an acute "medical" complication developed. Blood samples were taken into heparinized tubes and centrifuged at once, the plasma being stored at $-10^{\circ}$ C. until the estimations could be carried out. Serial

\footnotetext{
* Leverhulme Research Fellow, Middlesex Hospital Medical School, London W.1.

† Physician, Middlesex Hospital, London W.1.
}

measurements were made in some patients who required venepuncture in connexion with their illness.

Plasma 11-OHCS were estimated by the sulphuric acid fluorescence method (Mattingly, 1962) which was slightly modified. Only $0.5 \mathrm{ml}$. of plasma was extracted and an Aminco-Bowman Spectrophotofluorimeter was used which made it possible to check the emission spectrum from samples with low levels of 11-OHCS.

Plasma growth hormone was measured by radio-immunoassay, activated charcoal being used to separate the free from the bound labelled hormone. By this means it is possible to detect $0.4 \mathrm{~m} \mu \mathrm{g} . / \mathrm{ml}$. of plasma, the precision of the assay being $\pm 20 \%$ with $95 \%$ confidence (Jacobs, 1969). The results are expressed in terms of human growth hormone (NIH-GH-HS $722 \mathrm{~A}$, Wilhelmi, kindly supplied by the National Pituitary Agency), and we are indebted to Dr. A. D. Wright for the antiserum used.

Plasma 11-OHCS

The highest levels of plasma 11-OHCS were found in patients with unbalanced diabetes (Table I); the figures in patients with severe diabetic ketosis were higher than those with hyperosmolar non-ketotic coma (Fig. 1). Serial measurements were made on a number of patients, and the plasma 11-OHCS fell rapidly with treatment (Fig. 2). The patients with myocardial infarction had varying degrees of tissue destruction. Of those with only a minor degree, 13 had plasma 11-OHCS levels of less than $30 \mu \mathrm{g} . / 100 \mathrm{ml}$., whereas those with widespread infarction or who had been resuscitated after cardiac arrest usually had levels greater than $50 \mu \mathrm{g} . / 100 \mathrm{ml}$. Five of the patients with acute severe infections had unexpectedly low levels (Fig. 3); of these four were receiving steroids in a dosage which had not been increased when the infection developed. Point B in Fig. 3 is the reading from a woman aged 5.9 who had had a resection of the colon and ureteric reimplantation for malignant disease. She subsequently became very ill with fever and hypotension. Blood cultures grew pseudomonas, and the plasma 11-OHCS level at this time was $10 \cdot 7 \mu \mathrm{g} . / 100 \mathrm{ml}$. 
Treatment with steroids and appropriate antibiotics ultimately led to a complete recovery. Steroid therapy was then gradually withdrawn, and an A.C.T.H. test performed six months later gave a normal response.

TABLe I.-Plasma 11-OHCS in Patients with Acute Medical Illnesses

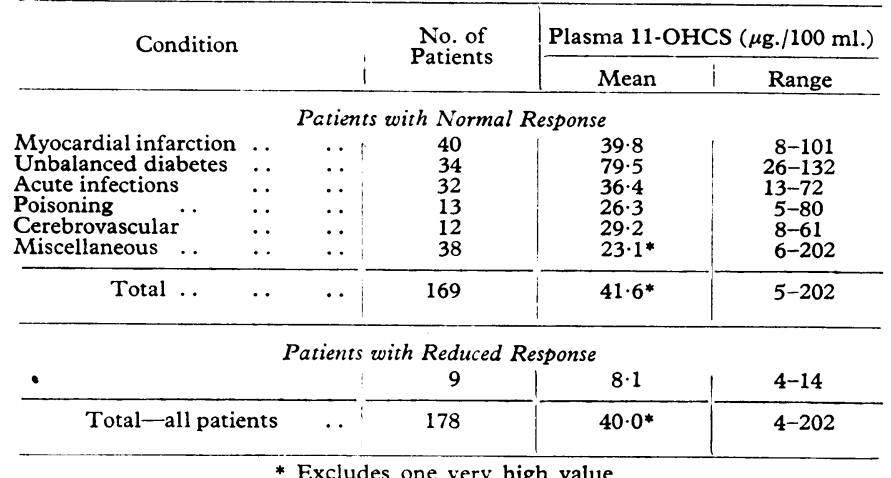

\section{Figure 1}

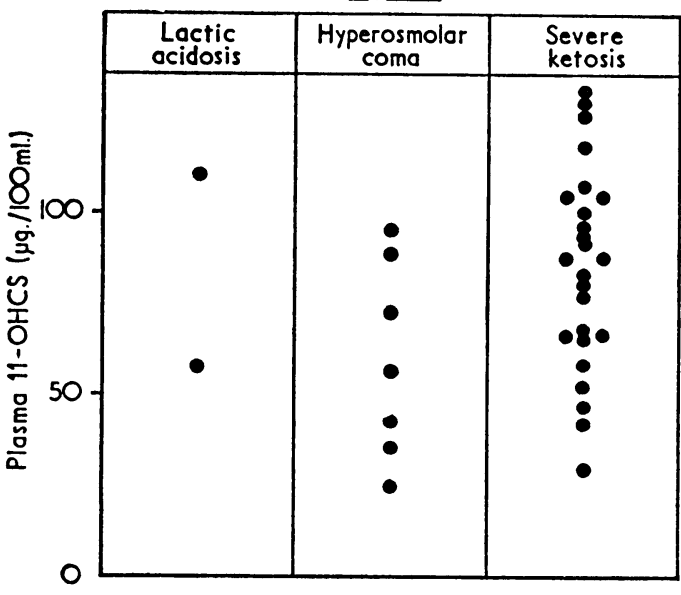

Figure 2
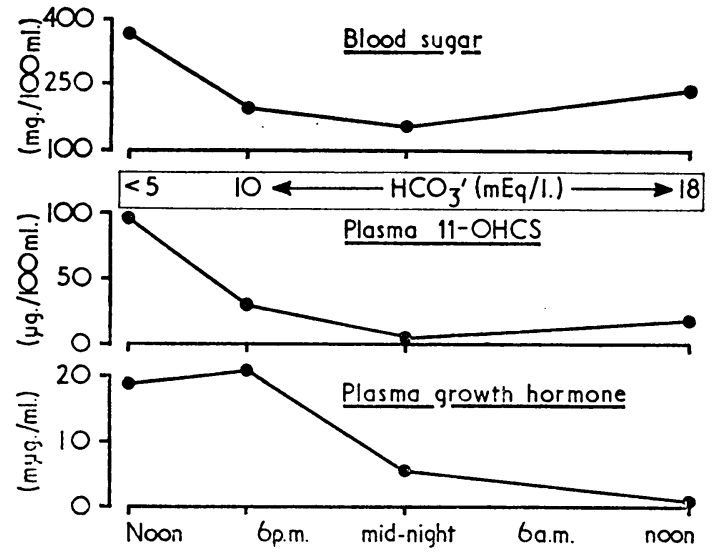

FIG. 1.-Plasma 11-OHCS in 34 patients with unbalanced diabetes. FIG. 2.-Changes of blood sugar, plasma bicarbonate, plasma 11-OHCS, and growth hormone concentrations in the 24 hours after starting treatment for severe diabetic ketosis in a woman aged 23 .

Nine patients had subnormal responses of plasma 11-OHCS to acute severe illnesses. Reference has already been made to five of these ; of the others, one had a severe myocardial infarct while on a small dose of prednisone ; one had an acute exacerbation of psoriasis with high fever, the pituitary adrenal axis having been suppressed by long-term steroid therapy; and one had fever and acute adrenal insufficiency following retrograde phlebography for an adrenal tumour. The ninth patient had had an adrenalectomy some years previously and was admitted following a haematemesis.

\section{Plasma Growth Hormone}

Plasma growth hormone concentrations were measured on at least one occasion in 139 of these patients (Table II). Those patients with unbalanced diabetes again had the highest levels

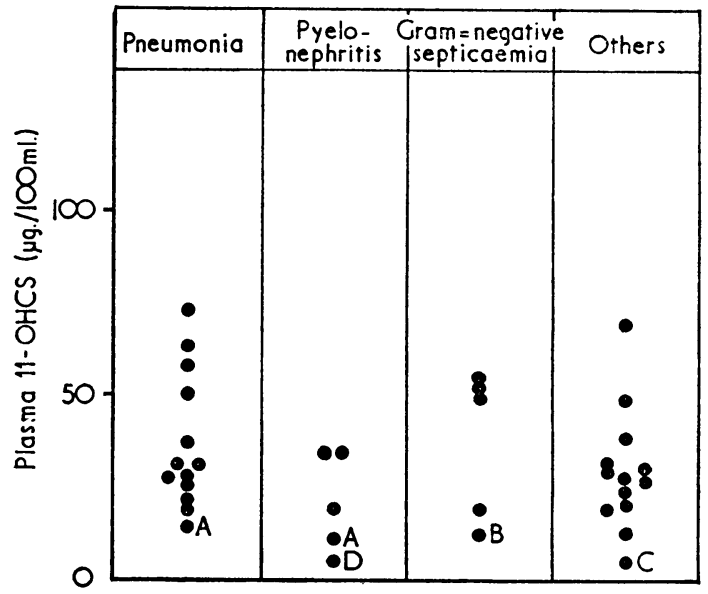

FIG. 3.-Plasma 11-OHCS in 36 patients with acute infections. One patient with pneumonia was investigated at the end of the study and the plasma 11-OHCS $(19.0$ $\mu \mathrm{g} . / 100 \mathrm{ml}$.) is not included. A, known cases of hypopituitarism. B, temporary adrenal cortical failure. C, pituitary suppression - steroid therapy. D, adrenalectomized patient.

(Fig. 4), and in addition showed an interesting contrast in the timing of the plasma growth hormone response. In severe ketosis the initial level was high but fell in response to treatment (Fig. 2); in patients with hyperosmolar non-ketoic coma it was low on admission but rose as the blood sugar fell (Fig. 5). Of eight patients who had unexpectedly high levels of plasma growth hormone (Table III) one woman aged 43 had mild diabetes which was treated with phenformin $(150 \mathrm{mg}$./day). She had been seen in the diabetic clinic on the morning of the day she died, and appeared well. On returning to the hospital in the evening she was vomiting and in a state of extreme anxiety. Blood was taken for sugar and lactic acid estimations, both of which were normal (the results shown

TABLE II.-Plasma Growth Hormone Concentrations in 139 Patients

\begin{tabular}{|c|c|c|c|c|c|}
\hline \multirow{2}{*}{\multicolumn{3}{|c|}{ Condition }} & \multirow{2}{*}{$\begin{array}{l}\text { No. of } \\
\text { Patients }\end{array}$} & \multicolumn{2}{|c|}{$\begin{array}{l}\text { Plasma Growth Hormone } \\
(\mathrm{m} \mu \mathrm{g} . / \mathrm{ml} .)\end{array}$} \\
\hline & & & & Mean & Range \\
\hline $\begin{array}{l}\text { Ayocardial infarction } \\
\text { nbalanced diabetes } \\
\text { cute infections } \\
\text { erebrovascular } \\
\text { eisoning } \\
\text { liscellaneous }\end{array}$ & $\begin{array}{l}\ldots \\
\because \\
\cdots \\
\cdots\end{array}$ & $\begin{array}{l}\cdots \\
\cdots \\
\cdots \\
\cdots\end{array}$ & $\begin{array}{r}31 \\
30 \\
27 \\
11 \\
9 \\
31\end{array}$ & $\begin{array}{l}4 \cdot 3 \\
9 \cdot 4 \\
4 \cdot 0 \\
1 \cdot 9 * \\
7 \cdot 4 \\
7 \cdot 9^{*}\end{array}$ & $\begin{array}{c}0-27 \cdot 5 \\
0 \cdot 5-35 \cdot 0 \\
0-13 \cdot 7 \\
0-320 \\
0-37 \cdot 5 \\
0-190\end{array}$ \\
\hline Total & .. & .. & 139 & $6 \cdot 1^{*}$ & $0-320$ \\
\hline
\end{tabular}

* Excludes the very high figures-190 and $320 \mathrm{~m} \mu \mathrm{g} . / \mathrm{ml}$.

TABLE III.-Details of Patients with Acute Medical Illnesses and Plasma Growth Hormone Levels Above $22 \mathrm{~m} \mu \mathrm{g} . / \mathrm{ml}$.

\begin{tabular}{|c|c|c|c|c|c|}
\hline Age & Sex & & Outcome & $\begin{array}{c}\text { Plasma } \\
\text { Growth } \\
\text { Hormone } \\
(\mathrm{m} \mu \mathrm{g} . / \mathrm{ml} .)\end{array}$ & $\begin{array}{c}\text { Plasma } \\
11-\mathrm{OHCS} \\
(\mu \mathrm{g} . / \\
100 \mathrm{ml} .)\end{array}$ \\
\hline \multirow{2}{*}{$\begin{array}{l}26 \\
41\end{array}$} & \multirow{2}{*}{$\begin{array}{l}\mathbf{M} \\
\mathbf{M}\end{array}$} & \multirow{6}{*}{$\begin{array}{l}\text { Haematemesis } \\
\text { Myocardial infarct, cardiac } \\
\text { arrest } \\
\text { Myocardial infarct, cardiac } \\
\text { arrest } \\
\text { Diabetes, lactic acidosis } \\
\text { Acute poisoning, ? pethidine } \\
\text { Acidosis, cardiac and renal } \\
\text { failure }\end{array}$} & Recovered & 22 & 50 \\
\hline & & & Recovered & $24 \cdot 3$ & 59 \\
\hline 65 & M & & & & \\
\hline \multirow{3}{*}{$\begin{array}{l}64 \\
23 \\
75\end{array}$} & \multirow{3}{*}{$\begin{array}{c}\mathbf{M} \\
\mathbf{F}\end{array}$} & & Died & 35 & $\begin{array}{l}30 \\
110\end{array}$ \\
\hline & & & Recovered & $37 \cdot 5$ & 21 \\
\hline & & & Recovered & $75 \cdot 5$ & 20 \\
\hline 43 & $\mathbf{F}$ & \multirow{2}{*}{$\begin{array}{l}\text { anxiety. Subsequent car- } \\
\text { diac arrest } \\
\text { Unconscious, cerebral } \\
\text { haemorrhage }\end{array}$} & Died & 190 & 202 \\
\hline \multirow[t]{2}{*}{71} & \multirow[t]{2}{*}{$\mathbf{M}$} & & & & \\
\hline & & & & & \\
\hline
\end{tabular}

号

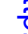


in Table III were obtained on this sample). An hour after admission the patient had a cardiac arrest from which she could not be resuscitated. The only abnormal finding at necropsy was moderate atheroma of the coronary arteries, but there was no evidence of myocardial infarction.

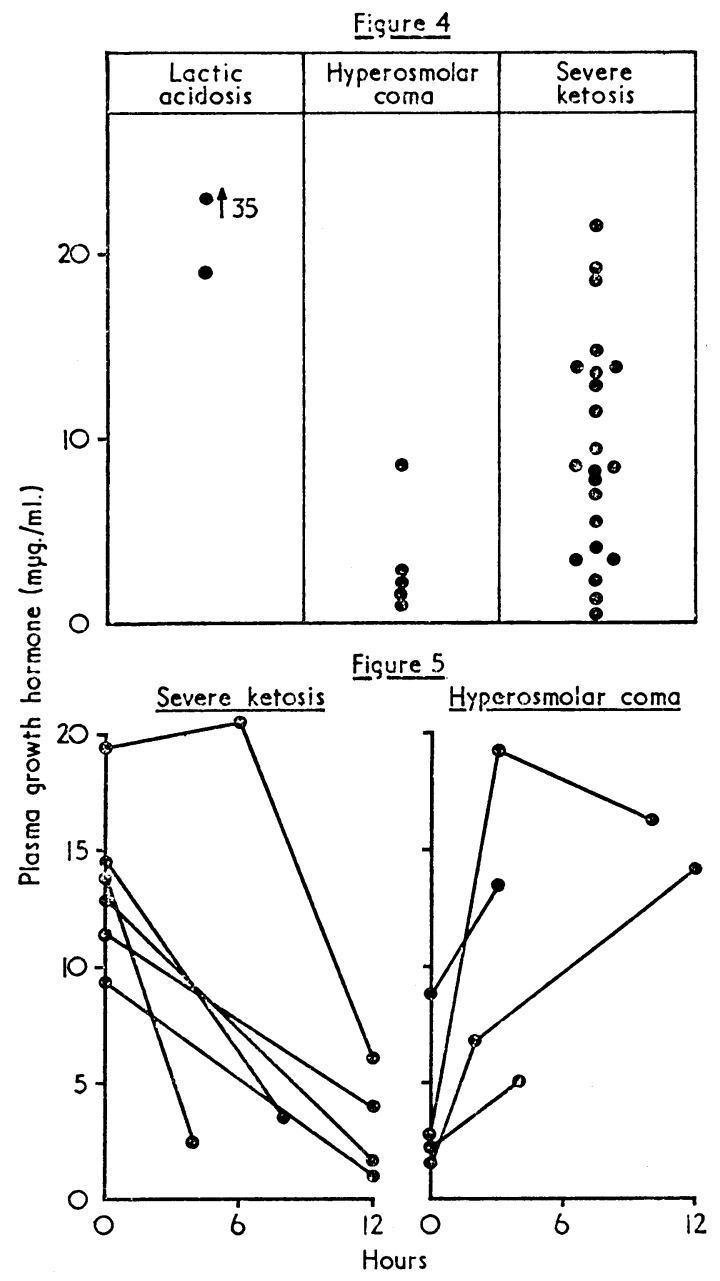

Fig. 4.-Placma growth hormone concentrations in 30 pati-nts w:th unbalanced diabetes. Fig. 5. - Changes in plasma srowth hormone conccntration in the first 12 hours after the stant of treatment of sevare diabetic k.tosis and hyp.resmolar non-ketotic diabetic coma.

\section{Discussion}

It has been known for many years that the plasma 17-hydroxycorticosteroid concentration is increased in patients with acute medical illnesses (Perkoff et al., 1954 ; Bayliss, 1955 ; Engel et al., 1955). Early studies showed that the high levels are partly the result of reduced removal of cortisol from the circulation (Sandberg et al., 1956; Glenchur and Doe, 1960) but there is no evidence of increased binding to protein (Murray, 1967). More recent studies have shown that cortisol secretion rates may be increased (Bassøe et al., 1965 ; Preeyasombat et al., 1965 ; Migeon et al., 1967 ; Nabarro, 1967 ; Roginsky and Duffy, 1967 ; Cornil et al., 1968), as may the excretion of free cortisol in the urine (Espiner, 1966 ; Bailey et al., 1967). Moreover, patients with acute medical illnesses have enhanced responses to a quick "Synacthen (tetracosactrin) test" of adrenal cortical function (Greig et al., 1968).

In severe diabetic ketosis very high levels of plasma 17-hydroxycorticosteroids were reported by Perkoff et al. (1954) and Klein et al. (1955). High cortisol secretion rates have been reported more recently (Nabarro, 1967 ; Roginsky and Duffy, 1967). The results given here confirm that there is a pronounced increase of adrenal cortical activity in all forms of severe diabetic imbalance. Plasma cortisol estimations have been reported in several series of patients with myocardial infarction (Klein and Palmer, 1963; Logan and Murdoch, 1966 ; Bailey et al., 1967 ; Sprunt and Browning, 1967). Our findings agree with most of these reports in suggesting that higher levels are found in patients with extensive infarcts and hypotension or after cardiac arrest. The plasma 11-OHCS levels may show a progressive rise with deterioration of the patient's clinical condition, and after a severe infarct the evening or midnight plasma cortisol may remain abnormal for 7 to 10 days. Similar findings have been reported in patients with congestive cardiac failure (Connolly and Wills, 1967; Knapp et al., 1967).

Cortisol secretion rates have been shown to be above normal in patients with acute bacterial infections (Bassøe et al., 1965 ; Migeon et al., 1967 ; Cornil et al., 1968) and virus encephalitis (Preeyasombat et al., 1965). Plasma corticosteroid levels in acute infectious illnesses have been reported by several groups (Glenchur and Doe, 1960 ; Murray, 1967), and studies have been made in patients with experimentally induced tularaemia (Beisel et al., 1967). The results are variable, and it has been suggested that they have little prognostic significance (Kass, 1962). The levels shown in Fig. 3 confirm the wide variation and there was no relation between the plasma 11-OHCS concentration, the clinical condition, and the outcome of the illness. In patients with severe acute illnesses and hypotension a level below $15 \mu \mathrm{g}$. per $100 \mathrm{ml}$. strongly suggests an inadequate adrenal response to the infection.

Corticosteroids given to patients with acute infectious illncoses and hypotension are either physiological replacements if the paticnt's adrenal cortical response is inadequate-probably a rare occurrence-or pharmacological agents to supplement the pationt's endogenous adrenal cortical activity. Despite evidence of the beneficial effects of large doses of steroids in dogs with cncotoxin shock (Lillehei et al., 1964) there are no convincing ciata $\mathrm{cn}$ their effect in patients with severe infections and hypotension (Kass, 1962 ; Shubin and Weil, 1966). In practice this is a situation in which treatment is urgent and cannot be delayed until the results of plasma steroid assavs are available. It secms reasonable therefore to give intravenous steroids to any patient in shock as the result of an acute infectious illness provided suitable antibiotics are being given. Whenever possible a plasma sample for measurement of 11-OHCS content should be taken before steroids are given and, as Mattingly and Tylcr (1965) have shown, a high level will nearly always be found.

The high level of plasma cortisol in acute medical illnesses results prezumably from hypothalamic stimulation, A.C.T.H. release, and increased cortisol secretion by the adrenal cortex. In patients with chronic illnesses and in terminal states defective hepatic metabolism of cortisol becomes increasingly important in the production of very high levels of plasma cortisol. The mechanism of hypothalamic stimulation in acute illnesses cannot be defined at the present time. Pain may be one cause (Shenkin, 1964), tissue necrosis may be concerned (Bailey et al., 1967), but fever is not necessarily associated with an increase of plasma cortisol (Kimball et al., 1968). Metabolic derangements apparently stimulate the hypothalamic-pituitary-adrenal axis, but the exact cause of the very high levels in severe diabetic ketosis is not known. In conscious patients anxiety and the effects of admission to hospital may play a part (Bayliss, 1955). Even less is known about how the increased cortisol level contributes to the maintenance of the blood pressure and circulation during an acute medical illness. All that is clear at the moment is that if there is failure of the adrenal cortical response the patient may be hypotensive and in a poor general condition and that rapid improvement may follow the administration of intravenous hydrocortisone. 
The lability of plasma growth hormone levels in normal subjects makes it difficult to interpret variations seen in acute medical illnesses. The figures reported here show that the concentration is increased in patients with severe diabetic ketosis and that it falls as the blood sugar falls in response to treatment. This is in keeping with the report by Unger (1965). The opposite trend seen in patients with hyperosmolar nonketotic diabetic coma suggests that in the latter, where some circulating insulin persists, glucose is entering the cells in that part of the nervous system where the stimulus to growth hormone release is inversely related to intracellular glucose availability. There is one report of an increase of growth hormone levels in sandfly fever (Beisel et al., 1968). The high values shown in Table III do not provide any meaningful pattern. The two patients with the highest levels $(190$ and $320 \mathrm{~m} \mu \mathrm{g} . / \mathrm{ml}$.) died and on necropsy no evidence of a pituitary adenoma was found.

The studies were carried out in the Institute of Clinical Research, the Middlesex Hospital Medical School, where H. S. J. has been Leverhulme Research Fellow. J.D.N. N. wishes to acknowledge support from the Clinical Research Committee of the Middlesex Hospital, the Royal College of Physicians of London-Joseph Senior White Fellowship-and the Medical Research Council. A preliminary account of some of the results was incorporated in a paper read by J.D.N.N. at the Royal Society of Medicine in October 1968 .

\section{REFERENCES}

Bailey, R. R., Abernethy, M. H., and Beaven, D. W. (1967). Lancet, 1, 970

Bassøe, H. H., Aarskog, D., Thorsen, T., and Støa, K. F. (1965). Acta Medica Scandinavica, 177, 701

Bayliss, R. I. S. (1955). British Medical fournal, 1, 495.

Beiscl, W. R., Bruton, J., Anderson, K. D., and Sawyer, W. D. (1967) fournal of Clinical Endocrinology and Metabolism, 27, 61.

Beisel, W. R., Woeber, K. A., Bartclloni, P. J., and Ingbar, S. H. (1968). fournal of Clinical Endocrinology and Metabolism, 28, 1220.
Connolly, C. K., and Wills, M. R. (1967). British Medical fournal, 2, 25.

Cornil, A., Copinschi, G., Leclercq, R., and Franckson, J. R. M. (1968), Acta Endocrinologica, 58, 1.

Engel, E., Helmreich, M. L., Hertoghe, J., Fabre, J., Muller, A. F., and Mach, R. S. (1955). Semaine des Hôpitaux de Paris, 31, 78.

Espiner, E. A. (1966). Fournal of Endocrinology, 35, 29.

Glenchur, H., and Doe, R. P. (1960). Clinical Research, 8, 222

Greig, W. R., Jasani, M. K., Boyle, J. A., and Maxwell, J. D. (1968). In The Investigation of Hypothalamic-Pituitary-Adrenal Function, edited by V. H. T. James and J. Landon, p. 175. London, Camedited by V. H. T. Jam

Jacobs, H. S. (1969). Fournal of Clinical Pathology. In press.

Kass, E. H. (1962). Transactions of the Association of American Physicians, $75,198$.

Kimball, H. R., Lipsett, M. B., Odell, W. D., and Wolff, S. M. (1968). fournal of Clinical Endocrinology and Metabolism, 28, 337

Klein, A. J., and Palmer, L. A. (1963). American fournal of Cardiology, 11, 332 .

Klein, R., Papadatos, C., Fortunato, J., and Byers, C. (1955). Fournal of Clinical Endocrinology and Metabolism, 15, 215 .

Knapp, M. S., Keane, P. M., and Wright, J. G. (1967). British Medical fournal, 2, 27.

Lillehei, R. C., Longerbeam, J. K., Bloch, J. H., and Manax, W. G. (1964). Annals of Surgery, 160, 682.

Logan, R. W., and Murdoch, W. R. (1966). Lanctt, 2, 521.

Mattingly, D.'(1962). Fournal of Clinical Pathology, 15, 374.

Mattingly, D., and Tyler, C. (1965). Proceedings of the Royal Society of Medicine, 58, 1010 .

Migeon, C. J., Kenny, F. M., Hung, W., and Voorhess, M. L. (1967) Pediatrics, 40, 163.

Murray, D. (1967). Fournal of Endocrinology, 39, 571

Nabarro, J. D. N. (1967). In The Human Adrenal Cortex, edited by G. E. W. Wolstenholme and R. Portar, p. 79. London, Churchill. Perkoff, G. T., Sandberg, A. A., Nelson, D. H., and Tyler, F. H. (1954). Archives of Internal Medicine, $93,1$.

Preeyasombat, C., Richards, C., Silverman, M., and Kenny, F. M. (1965). American fournal of Diseases of Children, 110, 370.

Roginsky, M. S., and Duffy, J. (1967). Excerpta Medica International Congress Series, No. 140 , p. 196

Sandberg, A. A., Eik-Nes, K., Migeon, C. J., and Samuels, L. T. (1956), fournal of Clinical Endocrinology and Metabolism, 16, 1001.

Shenkin, H. A. (1964). Neurology, 14, 1112.

Shubin, H. and Weil, M. H. (1966). Fournal of the American Medical Association, 197, 808 .

Sprunt, J. G., and Browning, M. C. K. (1967). Lancet, 1, 1160

Unger, R. H. (1965). Fournal of the American Medical Association, 191, 945.

\title{
Significance of Signs and Symptoms in Benign Prostatic Hypertrophy
}

\author{
J. E. CASTRO,* M.B., B.SC., F.R.C.S.ED. ; H. J. L. GRIFFITHS, † M.B., B.S., D.M.R.D. \\ R. SHACKMAN, $\ddagger$ M.B., B.S., F.R.C.S.
}

Cummary : Measurements of intravesical pressure, $\checkmark$ urinary flow rate, retrograde cystographic residual urine, reflux of contrast medium into the prostatic ducts, and radiological prostate size were made in 45 men with benign prostatic hypertrophy. These factors were all found to be good clinical indices of the degree of urethral resistance to micturition; on the other hand, there was no relation between the latter and the severity of symptoms.

\section{Introduction}

Sometimes there are virtually no doubts about the clinical indications for prostatectomy-for example, chronic retention

- Research Fellow, Urological Unit, Department of Surgery, Royal Postgraduate Medical School, London W.12; Honorary Registrar, Hammersmith Hospital, London W.12.

+ Registrar, Department of Radiodiagnosis, Hammersmith Hospital, London W.12.

‡ Professor of Urology, Hammersmith Hospital, London W.12. with overflow incontinence or recurrent acute painful retention -but it is not always so easy to assess the significance of symptoms such as hesitancy, dribbling, and urgency in this respect. Indeed, the interpretation of such symptoms is subject to wide variation (Wildbolz, 1958). If, however, it could be easily shown that there is high urethral resistance to micturition in patients with these symptoms (Claridge and Shuttleworth, 1964 ; Holm, 1964), prostatectomy would be more rational, for the aim of such operative treatment is primarily to reduce this resistance (Scott et al., 1967). The studies reported in this paper were designed to establish whether or not any correlation exists between the clinical and radiological findings and urethral resistance.

\section{Methods}

Forty-five patients, referred by their family doctor for urological assessment, with a provisional diagnosis of prostatism and with benign enlargement of the prostate on digital rectal 